Tomoki Nishiyama MD PhD, ${ }^{*} \dagger$ Takeshi Yokoyama DDs PhD, Kazuo Hanaoka MD PhD*

\title{
Midazolam improves postoperative epidural analgesia with continu- ous infusion of local anaesthetics
}

\begin{abstract}
Purpose: Midazolam has been shown to have an analgesic effect by single shot epidural administration. In this study, the effect of midazolam on continuous epidural infusion of bupivacaine was investigated to find a better combination for postoperative analgesia.

Methods: Sixty patients scheduled for gastrectomy were divided into three groups of 20 . The following mixtures, in $40 \mathrm{ml}$, were infused continuously over $12 \mathrm{hr}$ after surgery; $40 \mathrm{ml}$ bupivacaine $0.5 \%$ in Group C, bupivacaine $0.5 \% 38 \mathrm{ml}+10 \mathrm{mg}$ midazolam in Group MlO, and bupivacaine $0.5 \% 36 \mathrm{ml}+20 \mathrm{mg}$ midazolam in Group M20. If necessary, $50 \mathrm{mg}$ indomethacin suppository was administered. Blood pressure, heart rate, respiratory rate, analgesia score, and sedation score were monitored for $12 \mathrm{hr}$ after surgery. Amnesia and frequency of the administration of indomethacin suppository were also noted.

Results: Blood pressure, heart rate and respiratory rate showed no differences among the groups. Greater sedation was seen in Groups M10 and M20 compared with Group C during first $120 \mathrm{~min}(P<0.05)$. The number of patients with memory was larger in Group $C(18)$ than in Group $M 10(10, P=0.006)$ and Group $M 20(6, P<0.001)$. Better analgesia was obtained in patients receiving midazolam than in Group $C(P<0.05)$. The frequency of the indomethacin administration was $2.0 \pm 1.1(\mathrm{SD})$ in Group $C_{\text {, }}$ which was larger than in Group $M 10(1.1 \pm 0.9, P=0.035)$ and Group $M 20(1.2 \pm 0.7, P$ $=0.039$ ).
\end{abstract}

Conclusion: Adding midazolam to a continuous epidural infusion of bupivacaine provides better analgesia, amnesia and sedation than bupivacaine alone without side effects in patients undergoing laparotomy.

Objectif : L'effet analgésique du midazolam a été prouvé lors de l'administration épidurale d'une dose unique. La présente étude veut évaluer l'effet du midazolam sur la perfusion épidurale continue de bupivacaine afin de trouver une meilleure combinaison pour l'analgésie post opératoire.

Méthodes : Soixante patients devant subir une gastrectomie ont été répartis en trois groupes de 20 . Les mélanges suivants, en dose de $40 \mathrm{ml}$, ont été perfusés pendant 12 heures après la chirurgie : $40 \mathrm{ml}$ de bupivacaïne à $0,5 \%$ pour le groupe C, $38 \mathrm{ml}$ de bupivacaïne à $0,5 \%+10 \mathrm{mg}$ de midazolam pour le groupe $\mathrm{M} 10$ et $36 \mathrm{ml}$ de bupivacaïne à $0,5 \%+20 \mathrm{mg}$ de midazolam pour le groupe M20. Quand c'était nécessaire, on a administré $50 \mathrm{mg}$ d'indométhacine en suppositoires. La tension artérielle, les fréquences cardiaque et respiratoire de même que les niveaux d'analgésie et de sédation ont fait l'objet d'une surveillance de 12 heures après la chirurgie. On a aussi noté la présence d'amnésie et la fréquence d'administration d'indométhacine.

Résultats : Aucune différence intergroupe n’a été notée en ce qui concerne la tension artérielle et les fréquences cardiaque et respiratoire. Une sédation plus profonde a été observée dans les groupes $M 10$ et M20 comparés au groupe $C$ pendant les 120 premières minutes $(P<0,05)$. Le nombre de patients avec mémoire était plus grand dans le groupe $C(18)$ que dans le groupe $M 10(10, P=0,006)$ et le groupe $M 20(6, P<0,00 I)$. Une meilleure analgésie a été obtenue chez les patients recevant du midazolam que chez ceux du groupe $C(P<0,05)$. La fréquence d'administration de l'indométhacine était de 2,0 $\pm 1, I$ (écart type) dans le groupe $C$, ce qui était plus élevé que dans le groupe $M 10(1,1 \pm 0,9 P=0,035)$ et le groupe $M 20(1,2 \pm 0,7 P=0,039)$.

Conclusion : L'addition de midazolam à une perfusion épidurale continue de bipuvacaïne produit une analgésie, une perte mémoire et une sédation meilleures que la buipivacaïne employée seule et sans effets secondaires chez des patients qui subissent une laparotomie.

From the Department of Anesthesiology, The University of Tokyo, ${ }^{*}$ Faculty of Medicine, Department of Anesthesiology, Harbor - University of California Los Angeles Medical Center, $†$ Department of Anesthesiology and Resuscitology, Kochi Medical School.t

This work was carried out at the Department of Anesthesiology, The University of Tokyo, Faculty of Medicine.

Address correspondence to: Tomoki Nishiyama MD PhD, 1436 Brett Place, \#24, San Pedro CA 90732 USA. Phone: 1-310-222-3861; 
$\mathrm{T}$ HE GABA (gamma -aminobutyric acid) receptor in the spinal cord is involved in nociceptive mechanisms. ${ }^{1,2}$ Midazolam, the only clinically available water soluble benzodiazepine, has an analgesic action by its action on the benzodiazepine $\mathrm{GABA}_{\mathrm{A}}$ receptor complex. ${ }^{3}$ Intrathecal administration of midazolam produces anti-nociceptive effects in rats ${ }^{4}$ and in humans. ${ }^{5}$ In a human study by Serrao et al., 6 spinally administered midazolam relieved chronic mechanical low back pain. We reported that a single shot epidural injection of midazolam has an analgesic effect on postoperative somatic, but not visceral pain. ${ }^{7-10}$ Therefore, after some types of surgery such as laparotomy, it may be better to administer midazolam epidurally in combination with another agent which has an analgesic effect on visceral pain.

In most animal investigations, no signs of damage to the spinal cord or meninges were found in the rat, ${ }^{11,12}$ rabbit $^{13}$ and $\mathrm{cat}^{14}$. However, neurotoxicity has been reported in two studies. Malinowsky et al. ${ }^{15}$ and Svensson et al. ${ }^{16}$ showed spinal toxicity of intrathecally administered midazolam although the dose of subarachnoid midazolam was twice that giving reliable antinociception in rats. Thus, there is some controversy concerning the neurotoxicity of intrathecally administered midazolam. In humans, no adverse or irreversible effects have been observed after intrathecal ${ }^{5,6}$ or epidural ${ }^{11,12,13,17}$ administration of midazolam. Epidural administration of midazolam may be less toxic to the spinal cord because the drug concentration in cerebrospinal fluid is lower than after intrathecal administration.

Currently, continuous epidural administration of local anaesthetics and opioids is widely used for postoperative analgesia. To reduce the toxicity and blood pressure decrease by overdosage of local anaesthetics, opioids are commonly added. However, this combination may induce itching, nausea, vomiting, and/or respiratory depression by opioids. In our previous studies, ${ }^{7-10}$ single shot epidural administration of midazolam not only had no side effects but also induced some benefits for patients such as sedation and amnesia. There are no studies reporting the use of continuous epidural administration of midazolam for analgesia. Therefore, we investigated the analgesic effect of continuous epidural administration of midazolam with bupivacaine on postoperative analgesia.

\section{Subjects and methods}

After approval of the protocol by our institutional review board and written informed consent, 60 patients (aged 40 to $70 \mathrm{yr}, 45$ to $70 \mathrm{~kg}$ in body weight) scheduled for gastrectomy were enrolled in this study. They were divided into three groups of 20 patients at random by an envelope method. Patients who had used benzodiazepines chronically, who had a history of alcohol or other substance abuse, who had hepatic, renal, circulatory, or respiratory abnormalities were excluded from the study.

Midazolam $0.05 \mathrm{mg} \cdot \mathrm{kg}^{-1}$ with $0.01 \mathrm{mg} \cdot \mathrm{kg}^{-1}$ atropine (maximum $0.5 \mathrm{mg}$ ) im was administered $15 \mathrm{~min}$ before entering the operating room as routine premedication. After epidural catheterization into a single interspinal space $\left(\mathrm{T}_{7}-\mathrm{T}_{12}\right)$, anaesthesia was induced with sevoflurane $5 \%$, and nitrous oxide $50 \%$ in oxygen. Oro-tracheal intubation was facilitated with $0.15 \mathrm{mg} \cdot \mathrm{kg}^{-1}$ vecuronium. Before skin incision $6 \mathrm{ml}$ lidocaine $1.5 \%$ were administered epidurally. Anaesthesia was maintained with sevoflurane 1 to $2 \%$, nitrous oxide $67 \%$ in oxygen, and epidural block with intermittent $4 \mathrm{ml}$ to $8 \mathrm{ml}$ injection of lidocaine $1.5 \%$ (judged by the effect on skin incision of the first administration by the anaesthetist). Pancuronium was used as a muscle relaxant during surgery.

At the end of surgery, 4 to $8 \mathrm{ml}$ (same volume as used during surgery) bupivacaine $0.25 \%$ were injected epidurally. After tracheal extubation, continuous epidural infusion ( $40 \mathrm{ml}$ over $12 \mathrm{hr}$ ) was started using a balloon infuser (DIB catheter ${ }^{\mathrm{TM}}$, DIB International Co. Ltd., Tokyo, Japan). The contents of the balloon infuser were as follows; $40 \mathrm{ml}$ bupivacaine $0.5 \%$ (Marcain $^{\mathrm{TM}}$, Fujisawa Pharmaceutical Co. Ltd., Osaka, Japan) in Group C, $38 \mathrm{ml}$ bupivacaine $0.5 \%+10 \mathrm{mg}$ midazolam (Dormicum ${ }^{\mathrm{TM}}$, Yamanouchi Pharmaceutical Co. Ltd., Tokyo, Japan) in Group M10, and $36 \mathrm{ml}$ bupivacaine $0.5 \%+20 \mathrm{mg}$ midazolam in Group M20. In all groups, the total volume was $40 \mathrm{ml}$. Patients were observed in the intensive care unit and all variables were checked every $30 \mathrm{~min}$ during the first two hours then every hr until the end of the study. To keep the analgesia level sufficient (level 3 or less), $50 \mathrm{mg}$ indomethacin suppository was inserted if the level became 4 . The minimum interval before repeating the insertion of suppository was $30 \mathrm{~min}$.

Blood pressure, heart rate, respiratory rate, analgesia score, and sedation score were monitored for $12 \mathrm{hr}$ postoperatively. Memory retention and frequency of the administration of indomethacin suppository were also noted. Analgesia score was as follows, 1 : no pain at any time; 2 : no pain at rest; 3 : slight pain at rest but easily tolerable; 4: intolerable severe pain. Sedation score was as follows, ${ }^{7-9} 1$ : deep sleep (did not respond to a verbal command); 2 : sleep (respond to a verbal command); 3: no complaint or body movement, calm; 4: complaint with body movement, but calm; 5 : substantial complaining and body movement, not calm; 
6: a great deal of complaining and body movement accompanied by some excitement. These complaints did not include those about pain. Amnesia was tested on the next morning. The family visited the patient in the intensive care unit about one hr after starting the continuous infusion of epidural drugs as usual. On the next morning, the anaesthetist asked the patient whether he/she remembered the visit of his/her family. Other variables were checked by the nurse in intensive care unit, who did not know the content of a infuser.

All data are expressed as mean \pm standard deviation (SD). Demographic data (age, body weight, height, duration of surgery and lidocaine dosage) were compared among the groups using one way factorial analysis of variance (ANOVA) followed by Scheffe's F test. Time course changes in analgesia and sedation levels were evaluated by Friedman test. Analgesia and sedation scores and frequency of the administration of indomethacin suppository among the groups were analyzed by Kruskal-Wallis test. The chi-square test was used to compare gender, type of surgery, and memory retention among the groups. Blood pressure, heart rate and respiratory rate were analyzed by two way repeated measures ANOVA followed by contrast. A $P$ value less than 0.05 was considered statistically significant.

\section{Results}

There were no differences among the groups with regard to age, sex, body weight, height, type of surgery, duration of surgery and anaesthesia, or the dose of epidurally administered lidocaine during surgery (Table).

In Group M10, blood pressure decreased in the six hours after surgery $(P=0.028-0.041$, In the Figure 1 , only systolic blood pressure was indicated, because diastolic blood pressure showed the same change as systolic pressure.). However, no differences were seen among the three groups and no patients required treatment for hypotension. No differences were observed in heart rate among the three groups, while Groups C and M20 showed transient increase (Figure 1). Respiratory rate did not show any time or intergroup differences (Figure 1).

Greater sedation (lower sedation score) was seen in patients receiving midazolam (Groups $\mathrm{M} 10$ and $\mathrm{M} 20$, Figure 2) compared with those without midazolam (Group C) during the first two hr $(P=0.020-0.046)$. However, no difference was seen between Group M10 and Group M20. In no patients was excessively deep sedation nor a excitement seen in any groups.

The number of patients with memory of his/her family's visit was greater in Group C (continuous
TABLE Demographic data

\begin{tabular}{|c|c|c|c|}
\hline & Group C & Group MlO & Group $M 20$ \\
\hline Age (yr) & $58 \pm 10$ & $56 \pm 11$ & $58 \pm 11$ \\
\hline Sex (Male/Female) & $12 / 8$ & $11 / 9$ & $13 / 7$ \\
\hline Body weight (kg) & $58.7 \pm 8.5$ & $55.3 \pm 7.2$ & $59.0 \pm 8.9$ \\
\hline Height $(\mathrm{cm})$ & $158.9 \pm 12.3$ & $159.5 \pm 9.9$ & $162.7 \pm 9.5$ \\
\hline \multicolumn{4}{|c|}{ Surgery (number of patients) } \\
\hline Subtotal gastrectomy & 4 & 6 & 3 \\
\hline Distal gastrectomy & 16 & 14 & 17 \\
\hline \multicolumn{4}{|l|}{ Duration of } \\
\hline Surgery (min) & $215 \pm 98$ & $199 \pm 45$ & $188 \pm 72$ \\
\hline Anaesthesia (min) & $278 \pm 105$ & $243 \pm 65$ & $238 \pm 59$ \\
\hline Dose of lidocaine (mg) & $231 \pm 59$ & $205 \pm 63$ & $198 \pm 69$ \\
\hline
\end{tabular}

mean $\pm S D, n=20$ in each group

Group C: $40 \mathrm{ml}$ bupivacaine $0.5 \%$ in $12 \mathrm{hr}$

Group M10: $38 \mathrm{ml}$ bupivacaine $0.5 \%+10 \mathrm{mg}$ midazolam / $12 \mathrm{hr}$ Group M20: $36 \mathrm{ml}$ bupivacaine $0.5 \%+20 \mathrm{mg}$ midazolam $/ 12 \mathrm{hr}$ Dose of lidocaine is for epidural injection during surgery.

bupivacaine, $18 / 20)$ than in Group $M 10(10 / 20$, $P=0.006)$ and Group M20 $(6 / 20, P<0.001)$.

Better analgesia (lower score) was obtained in patients receiving midazolam (Figure 3). Group M20 showed better analgesia than Group M10 $10 \mathrm{~min}$ after the start of the infusion $(P=0.026)$. The frequency of administration of the indomethacin suppository was 2.0 \pm 1.1 ( 0 - 4; range) in Group C, which was larger than in Group $\mathrm{MlO}(1.1 \pm 0.9 ; 0-2, P=0.035)$ or Group M20 (1.2 \pm 0.7 times; $0-2, P=0.039)$.

\section{Discussion}

This study showed that adding midazolam to continuous epidural infusion of bupivacaine $0.5 \%$ induced better analgesia than bupivacaine alone, together with sedation and amnesia but without adverse effects. There was little difference of the effects between 10 $\mathrm{mg}$ midazolam and $20 \mathrm{mg}$ midazolam.

The increase in respiratory rate seen after a single shot epidural administration of midazolam in our previous studies ${ }^{8,9}$ was not observed in this continuous infusion study. Generally, after systemic administration of midazolam, respiratory rate increases to compensate for a decrease in tidal volume by a central effect. ${ }^{18}$ These results suggest that sufficient midazolam to affect the respiratory centre could pass enter the central nervous system by single shot administration but not by continuous infusion. Blood pressure reduction seen after systemic administration of midazolam, ${ }^{19}$ which was also induced by a single shot epidural administration of midazolam, ${ }^{8,10}$ was not observed in this study. Thus,' systemic side effects may be 
decreased by continuous infusion.

Sedation and amnesia are probably the result of the action of midazolam on the central nervous system. However, the route by which midazolam reaches the brain might not be via the systemic circulation but via the cerebrospinal fluid. To produce sedation by systemic administration of midazolam, serum concentration of $200 \mathrm{ng} \cdot \mathrm{ml}^{-1}$ are necessary while after epidural

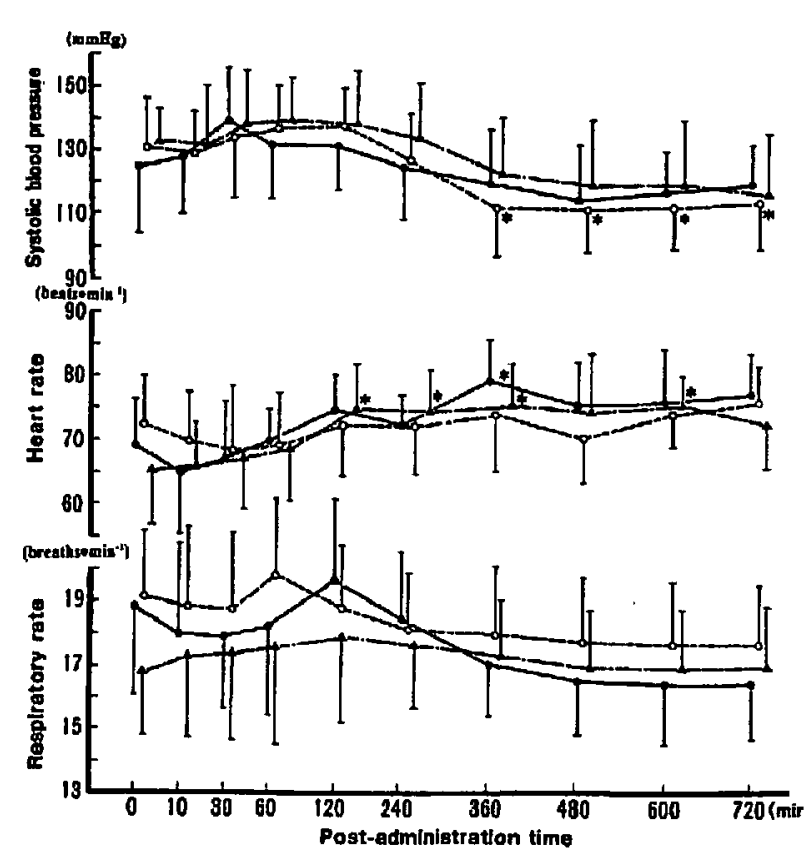

FIGURE 1 Blood pressure, Heart rate and Respiratory rate

The horizontal axis is the time after starting the continuous epidural infusion. Bars indicate standard deviation (SD). Closed circle: Group C; $40 \mathrm{ml}$ bupivacaine $0.5 \%$ in $12 \mathrm{hr}$, Open circle: Group M10; $10 \mathrm{mg}$ midazolam $+38 \mathrm{ml}$ bupivacaine $0.5 \%$ in $12 \mathrm{hr}$, Closed triangle: Group $\mathrm{M} 20 ; 20 \mathrm{mg}$ midazolam $+36 \mathrm{ml}$ bupivacaine in 12 hr. *: $P<0.05$ ps control value (time 0 )

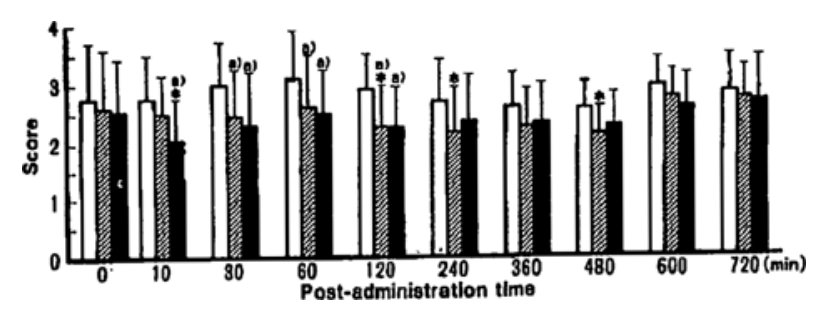

FIGURE 2 Sedation Score

The horizontal axis is the time after starting the continuous epidural infusion. Bars indicate standard deviation (SD). White column: Group C; $40 \mathrm{ml}$ bupivacaine $0.5 \%$, Cross-hatched column: Group M10; $10 \mathrm{mg}$ midazolam $+38 \mathrm{ml}$ bupivacaine $0.5 \%$, Black column: Group M20; $20 \mathrm{mg}$ midazolam $+36 \mathrm{ml}$ bupivacaine $0.5 \%$ * : $P<$ 0.05 vs control value (time 0), a): $P<0.05$ ps Group C

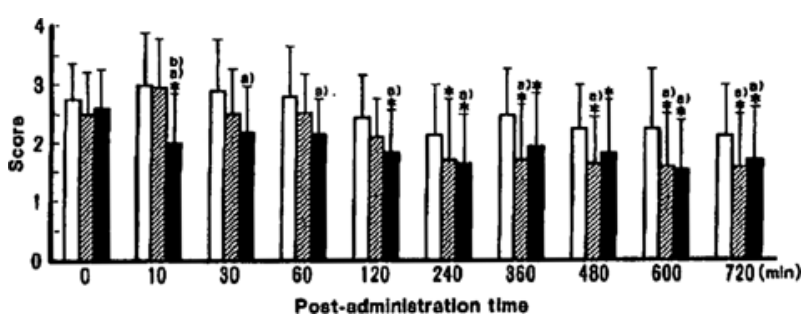

FIGURE 3 Analgesia Score

The horizontal axis is the time after starting the continuous epidural infusion. Bars indicate standard deviation (SD). White column: Group C; $40 \mathrm{ml}$ bupivacaine, Cross-hatched column: Group Ml0; $10 \mathrm{mg}$ midazolam $+38 \mathrm{ml}$ bupivacaine, Black column: Group M20; $20 \mathrm{mg}$ midazolam $+36 \mathrm{ml}$ bupivacaine. ${ }^{\star}: P<0.05$ vs control value (time 0), a): $P<0.05 v s$ Group C, b): $P<0.05 v s$ Group Ml0.

single shot administration of midazolam in our human study, ${ }^{7}$ patients were asleep with serum midazolam concentrations $<200 \mathrm{ng} \cdot \mathrm{ml}^{-1}$.

There was no clear dose dependence of the effect of epidural midazolam in the present study. In this study $10 \mathrm{mg}$ midazolam may have been sufficient to augment analgesia because bupivacaine $0.5 \%$ induced moderate analgesia.

The analgesic effect of epidural midazolam may be mainly attributed to action at the spinal cord because, after a single shot administration of midazolam, a dose dependent, segmental analgesia was observed. ${ }^{8}$ However, occasionally a total spinal like analgesic effect was obtained, ${ }^{8}$ which suggesting that the action is also at the brain. There are no experimental studies investigating the analgesic effect of epidural midazolam. Only intrathecal administration has been studied. The intrathecal single shot administration of midazolam induced reversible segmental antinociception in animals, ${ }^{20,21}$ which were similar to the results of our clinical study using epidural administration. ${ }^{8}$

We have demonstrated that adding midazolam to continuous epidural infusion of bupivacaine provides better analgesia, and greater amnesia and sedation than does bupivacaine alone without any side effects for patients undergone laparotomy. This combination may take the place of routinely used combination of opioids and local anaesthetics.

\section{References}

1 Hammond DL, Drower EJ. Effects of intrathecally administered THIP, baclofen and muscimol on nociceptive threshold. Eur J Pharmacol 1984; 103: 121-5.

2 Roberts $L A$, Beyer $C$, Komisaruk BR. Nociceptive responses to altered GABAergic activity at the spinal cord. Life Sci 1986; 39: 1667-74. 
3 Edwards M, Serrao JM, Gent JP, Goodchild CS. On the mechanism by which midazolam causes spinally mediated analgesia. Anesthesiology 1990; 73: 273-7.

4 Goodchild CS, Serrao JM. Intrathecal midazolam in the rat: evidence for spinally-mediated analgesia. $\mathrm{Br} \mathrm{J}$ Anaesth 1987; 59: 1563-70.

5 Goodchild CS, Noble J. The effects of intrathecal midazolam on sympathetic nervous system reflexes in man a pilot study. Br J Clin Pharmacol 1987; 23: 279-85.

6 Serrao JM, Marks RL, Morley SJ, Goodchild CS. Intrathecal midazolam for the treatment of chronic mechanical low back pain: a controlled comparison with epidural steroid in a pilot study. Pain 1992; 48: 5-12.

7 Nishiyama T, Odaka $\Upsilon$, Hirasaki A, Seto K. Epidural midazolam for treatment of postoperative pain. Masui 1991; 40: 1353-8.

8 Nishiyama T. The post-operative analgesic action of midazolam following epidural administration. Eur J Anaesthesiol 1995; 12: 369-74.

9 Nishiyama T, Hirasaki A, Odaka $\Upsilon$, Konishi H, Seot $K$, GotoI. Epidural midazolam with saline - optimal dose for postoperative pain. (Japanese) Masui 1992; 41 : 49-54.

10 Nishiyama T, Hirasaki A, Odaka $Y$, Mikane T, $K o b a y a s h i \quad O$, Seto $K$. Epidural midazolam with bupivacaine - Optimal dose for postoperative pain relief. (Japanese) Masui 1992; 41: 1113-8.

11 Serrao JM, Mackenzie JM, Goodchild CS, Gent JP. Intrathecal midazolam in the rat: an investigation of possible neurotoxic effects. Eur J Anaesthesiol 1990; 7: 115-22.

12 Schoeffler P, Auroy P, Bazin JE, Taxi J, Woda A. Subarachnoid midazolam: histologic study in rats and report of its effect on chronic pain in humans. Reg Anesth 1991; 16: 329-32.

13 Auroy $P$, Scboeffler $P$, Maillot $C$, Haberer JP, Woda A. Chronic intrathecal midazolam. Histological study. (French). Ann Fr Anesth Reanim 1988; 7: 81-2.

14 Nishiyama $T$, Hanaoka $K$. Histopathologic study of spinally administered midazolam in cats. $\mathrm{Br} \mathrm{J}$ Anaesth 1997; 78: S119.

15 Malinowsky J-M, Cozian A, Lepage J- $\Upsilon$, Mussini J-M, Pinaud $M$, Souron $R$. Ketamine and midazolam neurotoxicity in the rabbit. Anesthesiology $1991 ; 75: 91-7$.

16 Svensson $B A$, Welin $M$, Gordh $T J r$, Westman J. Chronic subarachnoid midazolam (Dormicum) in the rat. Morphologic evidence of spinal cord neurotoxicity. Reg Anesth 1995; 20: 426-34.

17 Crevat-Pisano P, Dragna S, Granthil C, Coassolo P, Cano JP, Francois $G$. Plasma concentrations and pharmacokinetics of midazolam during anaesthesia. J Pharm Pharmacol 1986; 38: 578-82.
18 Berggren L, Eriksson I, Mollenbolt $P$, Sunzel M. Changes in respiratory pattern after repeated doses of diazepam and midazolam in healthy subjects. Acta Anaesthesiol Scand 1987; 31: 667-72.

19 Schulte-Sasse U, Hess W, Tarnow J. Haemodynamic responses to induction of anaesthesia using midazolam in cardiac surgical patients. Br J Anaesth 1982; 54: 1053-8.

20 Niv D, Whitwam JG, Loh L. Depression of nociceptive sympathetic reflexes by the intrathecal administration of midazolam. Br J Anacsth 1983; 55: 541-7.

21 Babar $M$, Coben $M L$, Grinshpon $Y$, Chanimov $M$. Spinal anaesthesia with midazolam in the rat. Can J Anaesth 1997; 44: 208-15. 